\title{
Chapter 4 \\ Conservation Tillage Assessment for Mitigating Greenhouse Gas Emission in Rainfed Agro-Ecosystems
}

\author{
Muhajir Utomo
}

\begin{abstract}
Global warming due to greenhouse gas emissions is currently receiving considerable attention worldwide. Agricultural systems contribute up to $20 \%$ of this global warming. However, agriculture can reduce its own emissions while increasing carbon sequestration through use of recommended management practices, such as consernvation tillage (CT). The objective of this paper is to review the role of long-term CT in mitigating greenhouse gas emissions during corn production in rainfed tropical agro-ecosystems. The types of conservation tillage were notillage (NT) and minimum tillage (MT). In a long-term plot study, $\mathrm{CO}_{2}$ emission from CT throughout the corn season was consistently lower than that from intensive tillage (IT). The cumulative $\mathrm{CO}_{2}$ emissions of NT, MT, and IT in corn crops were 1.0, 1.5, and 2.0 $\mathrm{Mg} \mathrm{CO} \mathrm{CO}_{2}-\mathrm{C} \mathrm{ha}{ }^{-1}$ season $^{-1}$, respectively. Soil carbon storage at 0-20 cm depth after 23 years of NT cropping was $36.4 \mathrm{Mg} \mathrm{C} \mathrm{ha}^{-1}$, or $43 \%$ and $20 \%$ higher than the soil carbon strorage of IT and MT, respectively. Thus, NT had sequestered some $4.4 \mathrm{Mg} \mathrm{C} \mathrm{ha}^{-1}$ of carbon amounting to carbon sequestration rate of $0.2 \mathrm{Mg} \mathrm{C} \mathrm{ha}^{-1}$ year $^{-1}$. IT, on the other hand, had depleted soil carbon by as much as 6.6 $\mathrm{Mg} \mathrm{C} \mathrm{ha}^{-1}$, yielding a carbon depletion rate of $0.3 \mathrm{Mg} \mathrm{C} \mathrm{ha}^{-1}$ year $^{-1}$. Assessment of the farmer's corn fields confirmed these findings. $\mathrm{CO}_{2}$ emission from $\mathrm{CT}$ corn farming was similar to that of rubber agroforest and lower than IT corn farming. Based on carbon balance analysis, it can be concluded that corn crops in tropical rainfed agro-ecosystems were not in fact net emitters, and that NT was a better net sinker than other tillage methods.
\end{abstract}

Keywords Conservation tillage $\bullet \mathrm{CO}_{2}$ emission $\bullet$ Carbon storage

\footnotetext{
M. Utomo (ه)

Agro-Technology Department, Faculty of Agriculture, University of Lampung, Jl. Sumantri Brojonegoro \#1, Bandar Lampung 35145, Indonesia e-mail: mutomo2011@gmail.com
} 


\subsection{Introduction}

Global warming due to greenhouse gas (GHG) emissions is currently receiving consider-able attention worldwide. The impact of human activities on the atmosphere and the accompanying risk of long-term climate change on a global-scale are by now familiar topics to many people (Paustian et al. 2006). Global temperature rose $0.6{ }^{\circ} \mathrm{C}$ during the twentieth century, and is projected to increase by $1.5-5.8{ }^{\circ} \mathrm{C}$ during the twenty-first century. Historical records clearly show an accelerating increase in atmospheric GHG concentrations over the past 150 years (Intergovernmental Panel on Climate Change (IPCC) 2001). This is attributed to the advance of greenhouse gases such as $\mathrm{CO}_{2}, \mathrm{CH}_{4}$, and $\mathrm{N}_{2} \mathrm{O}$, in particular, due to the anthropogenic activities. Among the greenhouse gases, $\mathrm{CO}_{2}$ is the most important gas, accounting for $60 \%$ of global warming (Rastogi et al. 2002; Ruddiman 2003; Lal 2007). While most of the increase is due to $\mathrm{CO}_{2}$ emissions from fossil fuels, land use and agriculture play significant roles. Overall, agricultural activities along with land use change, which predominantly occurs in the tropics, globally account for about one-third of the warming effect from increased GHG concentrations (Cole et al. 1997). In fact, although agriculture is its self subject to environmental risk due to global warming, ironically it is also estimated to contribute up to $20 \%$ of global anthropogenic $\mathrm{CO}_{2}$ emissions (Intergovernmental Panel on Climate Change (IPCC) 2006; Haile-Mariam et al. 2008). In Indonesia specifically, agriculture, land use change, and forests combine to contribute as much as $53 \%$ of $\mathrm{CO}_{2}$ emissions (Boer 2010). Agro-ecosystems emit $\mathrm{CO}_{2}$ emission through direct use of fossil fuels in food production, indirect use of embodied energy in inputs, and cultivation of soils that cause the loss of carbon through decomposition and erosion (Ball and Pretty 2002).

The difference compared with fossil fuel based sectors, however, is that land use and agriculture have the opportunity to mitigate GHG emission through recommended management practices (RMP). Therefore, producers, scientists, and planners are faced with the challenge of increasing agricultural production without aggravating the risks of GHG emissions. In this regard, the management of soil resources in general and that of soil organic carbon (SOC) in particular, is extremely important. The world's soil resources may be the key factor in the creation of an effective carbon sink and mitigation of the greenhouse effect (Lal 1997). By employing RMP, agro-ecosystems can act as sinks that can both sequester carbon (C) and reduce $\mathrm{CO}_{2}$ emission (Pretty and Ball 2001; Lal 2007). Conservation tillage as a RMP can enhance SOC, thus reducing agriculture's potential for global warming (Rastogi et al. 2002; Lal 2007; Smith 2010). In fact, in the Kyoto Climate Protocol and IPCC Guidelines for National Greenhouse Gas Inventories, conservation tillage is listed as an option for carbon sequestration (Sedjo et al. 1998; Eggleston et al. 2006).

Worldwide adoption of CT, and particularly no-tillage, has expanded rapidly since about 1990, particularly in the United States, South American countries, and Africa (Triplett and Dick 2008). As in other countries, CT in Indonesia which generally consists of no-tillage (NT) and minimum tillage (MT), was initially promoted by a few CT researchers in the 1980's. Farmers themselves successfully adopted 
and practiced CT in the 1990s due to the fact that it requires less cost and labor, yet maintains at least the same crop yield as IT. This was the case particularly in regions with labor shortages, such as Sumatra, Borneo, and Celebes (Utomo 2004). Then in 1998, CT was explicitly advocated in a national land preparation policy, resulting in increasing adoption of the techniques, particularly for corn production (Utomo et al. 2010a). As the second most important food crop in Indonesia, corn is mostly planted in rainfed agro-ecosystems. In Lampung Province, the area of corn harvested in 2011 was 380.917 ha, or $46 \%$ of the total area of Sumatra's corn belt (Badan Pusat Statistik BPS 2012). However, rainfed agro-ecosystems, which account for about $91 \%$ of total agricultural land in Indonesia, are inherently prone to degradation. To sustain these vulnerable agro-ecosystems, therefore, CT should be implemented and further improved.

The aim of this paper is to review research and assessment findings both from a long-term plot and from farmers' fields, in order to evaluate the potential of CT to mitigate $\mathrm{CO}_{2}$ emissions in Indonesia's rainfed agro-ecosystems. In this paper, mitigation of $\mathrm{CO}_{2}$ emissions is defined as a technological effort both to reduce GHG emissions and to sequester carbon in soils.

\subsection{Soil, Carbon Dioxide Emission, and Conservation Tillage}

Soil is a powerful natural sink of carbon in terrestrial ecosystems. Natural soils can retain carbon in stable microaggregates for up to hunded and thousands of years unless environmental conditions are changed and stable soil structure is damaged. Cultivation practices, such as plowing, break soil aggregates, exposing formerly protected SOC in soil to microbial attacks, and thus accelerating decomposition and $\mathrm{CO}_{2}$ emission to the atmosphere (Luo and Zhou 2006). In general, these respiratory carbon losses from soil can be attributed to biological and chemical processes within the soil that may include $\mathrm{CO}_{2}$ from soil organic matter and crop residue decomposition, and from root respiration (Rastogi et al. 2002; Al-Kaisi and Yin 2005). Moreover, Luo and Zhou (2006) stated that $\mathrm{CO}_{2}$ emitted from soil ecosystems constitutes part of the cabon cycle, and is mostly produced as a result of the soil respiration process. Depending on the sources of carbohydrate substrate supply, $\mathrm{CO}_{2}$ production in the soil can be attributed to root respiration, microbial respiration in the rhyzosphere, litter decomposition, and oxidation of soil organic matter.

In tropical agro-ecosystems, soil respiration and decomposition happen more quickly, resulting in higher $\mathrm{CO}_{2}$ emission and less $\mathrm{C}$ sequestration than in cooler climates (Desjardins, et al. 2002). Cultivation for land preparation produces a favorable soil microenvironment that can accelerate microbial decomposition of plant residues. Cultivation or intensive tillage (IT) is any tillage that requires clean and loose top soil for seed to grow. For this reason, soil should be totally tilled and no mulch is needed. But over the long-term, IT decreases soil quality and soil productivity (Rastogi et al. 2002; Paustian et al. 2006; Luo and Zhou 2006). Soil degraded by cultivation is also more susceptible to erosion, which carries carbon to 
rivers and oceans, where it is partially released into the atmosphere by outgassing (Luo and Zhou 2006).

Soil resources have the potential capacity to sequester carbon. Based on the principles of either increasing plant carbon input or slowing soil carbon decomposition rates, soil carbon can be sequestered through a variety of recommended management practices (RMP). Conservation tillage as a RMP is a tillage system that keeps at least $30 \%$ of the soil surface covered by plant residue and reduces soil disturbance (Lal 1989; Utomo 2004). The function of crop residue covering the soil surface is to protect the soil from sun, rain, and wind, and to feed the biota. Crop residue serves as a substrate that is converted to microbial biomass and soil organic matter, and has the potential to enhance carbon sequestration in agricultural soils (Wright and Hons 2004). There are several types of CT, including (a) no-tillage: the soil is left undisturbed except for hills, slots, or bands; and weeds are controlled primarily with herbicide; (b) ridge tillage: soil is undisturbed, and planting is on ridges; (c) strip tillage: soil is undisturbed, and 1/3 of the soil surface is tilled; (d) mulch tillage: soil is totally tilled, with mulch on the soil surface; and (e) reduced tillage/minimum tillage: at least $30 \%$ of the soil surface is covered by plant residue (Lal 1989; Utomo 2004).

Long-term CT involving crop residue and less tillage can reduce soil erosion and improve soil organic matter. Therefore, through its effect on $\mathrm{C}$ dynamics, aggregation, and soil structure, and its interaction with cropping systems, CT is expected to result in lower $\mathrm{CO}_{2}$ emissions and higher soil C sequestration than IT (Lal 1997).

\subsection{Reducing Carbon Dioxide Emission}

\subsubsection{Carbon Dioxide Emission at the Long-Term Plot}

Field research on mitigation of $\mathrm{CO}_{2}$ gas emissions from a corn plot was conducted from 2009 to 2011 as part of the long-term plot research commenced in 1987 in Lampung, Indonesia $\left(105^{\circ} 13^{\prime} \mathrm{E}, 05^{\circ} 21^{\prime} \mathrm{S}\right)$. The experiment was a factorial, randomized complete block design, with 4 replications. Tillage treatments comprised conservation tillage (NT and MT), and IT, while nitrogen fertilization rates were 0,100 , and $200 \mathrm{~kg} \mathrm{~N} \mathrm{ha}^{-1}$ (Utomo et al. 1989).

Regardless of $\mathrm{N}$ fertilization, average $\mathrm{CO}_{2}-\mathrm{C}$ emission from tillage treatment measured before plowing was $3.3 \mathrm{~kg} \mathrm{CO}_{2}-\mathrm{C} \mathrm{ha}^{-1} \mathrm{day}^{-1}$. It appears that just one day after plowing (1 DAP), $\mathrm{CO}_{2}-\mathrm{C}$ emission from IT increased sharply to reach a maximum magnitude of $14.6 \mathrm{~kg} \mathrm{CO} \mathrm{CO}_{2}-\mathrm{C} \mathrm{ha}{ }^{-1} \mathrm{day}^{-1}$. Thereafter, $\mathrm{CO}_{2}-\mathrm{C}$ emission from IT dropped sharply at 3 DAP and then gradually declined, while emission from CT was relatively level to the end of the season (Fig. 4.1a) (Utomo et al. 2012). This was similar to research findings by Al-Kaisi and Yin (2005), which found that $\mathrm{CO}_{2}$ emission was generally lower with less tillage compared to moldboard plow usage, with the greatest differences occurring immediately after tillage operations. 

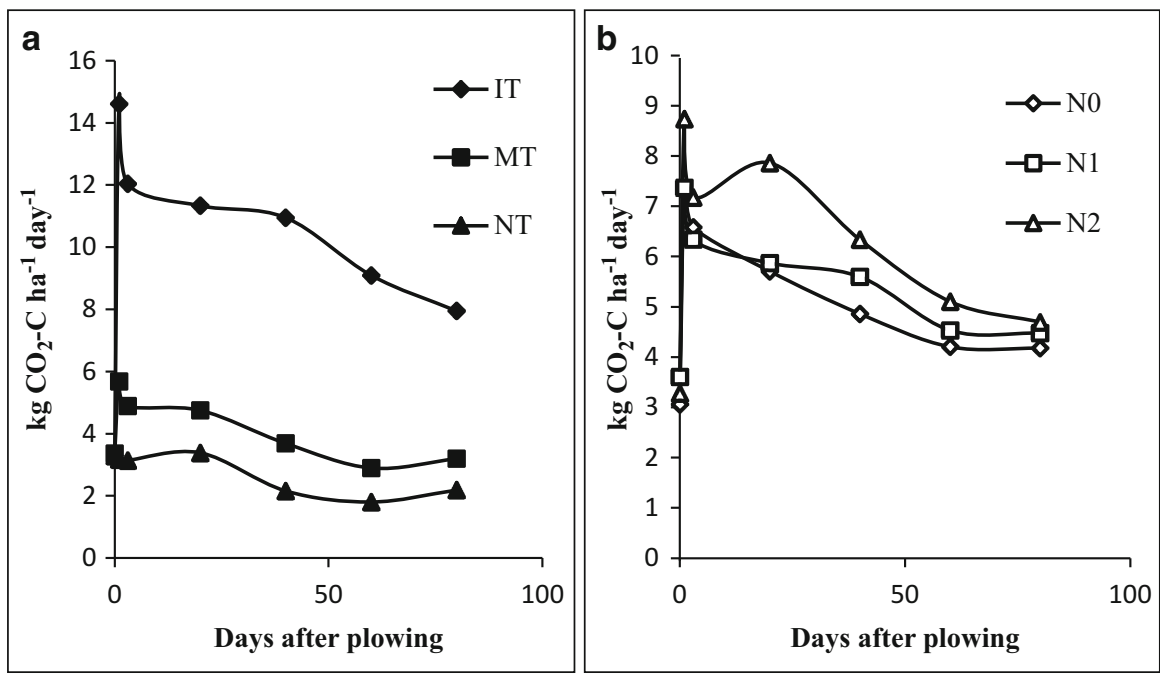

Fig. 4.1 Pattern of $\mathrm{CO}_{2}-\mathrm{C}$ emission in corn season as affected (a) conservation tillage, and (b) $\mathrm{N}$ fertilization; IT =intensive tillage, $\mathrm{MT}=$ minimum tillage, $\mathrm{NT}=$ no-tillage, $\mathrm{N} 0=0 \mathrm{~kg} \mathrm{~N} \mathrm{ha}{ }^{-1}$, $\mathrm{N} 1=100 \mathrm{~kg} \mathrm{~N} \mathrm{ha}^{-1}, \mathrm{~N} 2=200 \mathrm{~kg} \mathrm{~N} \mathrm{ha}^{-1}$ (Utomo et al. 2012)

During a single season, NT and MT reduced the $\mathrm{CO}_{2}-\mathrm{C}$ emissions of corn production at the long-term plot to $76 \%$ and $62 \%$ of IT based emission, respectively. This was because tillage broke and inverted the soil to allow rapid $\mathrm{CO}_{2}$ loss and $\mathrm{O}_{2}$ entry, and mixed together the residues and organic particles that could enhance microbial attack (Reicosky 2001; Rastogi et al. 2002; Smith and Collins 2007). On the other hand, CT reduced gas diffusivity and air-filled porosity, and kept SOC unexposed, resulting in a lower $\mathrm{CO}_{2}$ emission than that of IT (Rastogi et al. 2002). These findings are in agreement with those reported by Reicosky (2001); Desjardins et al. (2002); Scala et al. (2005); Brye et al. (2006).

Although the effects were not as strong as those of tillage treatment, $\mathrm{N}$ fertilization treatment in corn season also consistently increased $\mathrm{CO}_{2}-\mathrm{C}$ emission (Fig. 4.1b). Emissions of $\mathrm{CO}_{2}$ at the $200 \mathrm{~kg} \mathrm{~N}^{-1}$ fertilization rate were consistently higher than those at the 0 and $100 \mathrm{~kg} \mathrm{~N} \mathrm{ha}^{-1}$ rates (Utomo et al. 2012). When tillage was combined with $\mathrm{N}$ fertilization, the synergetic effect was clearly observed. With residual $200 \mathrm{~kg} \mathrm{~N} \mathrm{ha}^{-1}, \mathrm{CO}_{2}$ emission from IT treatment at $1 \mathrm{DAP}$ was the highest among treatment combinations, while MT with any $\mathrm{N}$ rate fertilizations produced the second highest $\mathrm{CO}_{2}$ emission, and $\mathrm{NT}$ was the lowest.

The higher $\mathrm{CO}_{2}-\mathrm{C}$ emission when combining IT with a higher $\mathrm{N}$ rate was associated with the synergetic effect of tillage and $\mathrm{N}$ fertilization treatments. Combination of IT and an optimum $\mathrm{N}$ rate created a soil micro climate and available $\mathrm{N}$ that produced more soil $\mathrm{CO}_{2}$ emission (Utomo et al. 2012). 

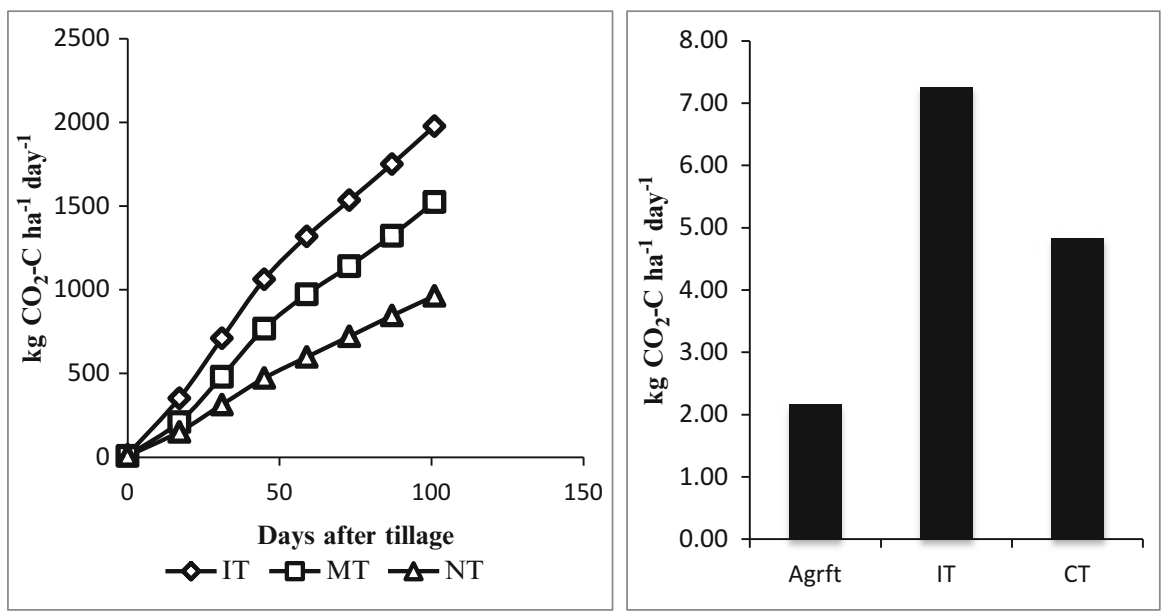

Fig. 4.2 Cumulative $\mathrm{CO}_{2}$-C emission of corn at long-term plot (left $)$ and $\mathrm{CO}_{2}-\mathrm{C}$ emission at farmers' fields $($ right $)$; Agrft = agroforest, $\mathrm{IT}=$ intensive tillage, $\mathrm{MT}=$ minimum tillage, $\mathrm{NT}=$ no-tillage and $\mathrm{CT}=$ conservation tillage (Utomo et al. 2010b; Utomo et al. 2011)

\subsubsection{Cumulative $\mathrm{CO}_{2}$ Emission at the Long-Term Plot}

Cumulative soil $\mathrm{CO}_{2}$ emission was set using the equation proposed by Al-Kaisi and Yin (2005). Cumulative soil $\mathrm{CO}_{2}$ emissions of IT, MT, and NT were 1.98, 1.53 and $0.96 \mathrm{Mg} \mathrm{CO}_{2}-\mathrm{C} \mathrm{ha}^{-1}$ season $^{-1}$, respectively (Fig. 4.2, left). During a single season, NT reduced $\mathrm{CO}_{2}$ emission to $52 \%$ of IT based emission, while MT reduced emission to $23 \%$ that of IT (Utomo et al. 2011).

Although these figures are somewhat lower than those of the average bases method, the value of cumulative $\mathrm{CO}_{2}$ emission is much closer to continuous $\mathrm{CO}_{2}$ measurement. This finding is in accordance with findings reported by Al-Kaisi and Yin (2005). They reported that cumulative soil $\mathrm{CO}_{2}$ emission from MT was 19 to $41 \%$ lower than that from moldboard plow usage, and NT with residue was $24 \%$ lower than NT without residue during the 480-h measurement period.

\subsubsection{Carbon Dioxide Emission Assessment in Farmers' Fields}

In 2010, assessment of $\mathrm{CO}_{2}$ emission in farmers' fields was conducted in East Lampung District, Lampung Province, Indonesia $\left(105^{\circ} 28^{\prime} 35^{\prime \prime}-105^{\circ} 28^{\prime} 39^{\prime \prime} \mathrm{E}\right.$, $\left.05^{\circ} 19^{\prime} 22^{\prime \prime}-05^{\circ} 19^{\prime} 26^{\prime \prime} \mathrm{S}\right)$. The soil texture was loam to clay loam, with soil $\mathrm{pH}_{\mathrm{H} 2 \mathrm{O}}$ 5.1-5.4, total soil N 0.15-19\%, soil organic C 0.7-1.0\%, available P 1.9-4.1 ppm, CEC 10.2-13.2 me $100 \mathrm{~g}^{-1}$, and BD 1.2-1.3 $\mathrm{Mg} \mathrm{m}^{-3}$ (Utomo et al. 2010b).

In this assessment, a similar effect was clearly shown, but the effect was not as marked as in the plot experiment (Fig. 4.2, right). This was not only because the 
farmer applied less fertilizer, but also because during MT farming mulch covered only around $40 \%$ of the soil surface, while in the plot experiment it covered around $90 \%$. Emission of $\mathrm{CO}_{2}$ from IT was the highest, while emission from rubber agroforest was the lowest (Utomo et al. 2010b). Rubber agroforest reduced $\mathrm{CO}_{2}$ emission to $70 \%$ that of IT farming, while MT farming reduced it as much as $33 \%$ (Fig. 4.2, right).

\subsection{Enhancing Carbon Sequestration}

\subsubsection{Soil Carbon Storage}

At the long-term plot, the highest soil $\mathrm{C}$ storage after 23 years of cropping at 0-20 cm depth was obtained by treatment combining NT with a higher N rate, while the lowest soil C strorage was in IT with $0 \mathrm{~kg} \mathrm{~N} / \mathrm{ha}$ as shown in Fig. 4.3, left. No-tillage and MT resulted in soil C storage $43 \%$ and $20 \%$ higher than IT, respectively. The initial carbon storage at 0-20 cm depth in 1987 (when this long-term plot was established) was $32.0 \mathrm{Mg} \mathrm{ha}^{-1}$ (Utomo et al. 2010a). Thus, during 23 years of cropping, NT had sequestered as much as $4.4 \mathrm{Mg} \mathrm{C} \mathrm{ha}^{-1}$ of carbon, amounting to a carbon sequestration rate of $0.2 \mathrm{Mg} \mathrm{C} \mathrm{ha}^{-1}$ year $^{-1}$. In contrast, IT had depleted 6.6 $\mathrm{Mg} \mathrm{C} \mathrm{ha}{ }^{-1}$ of carbon, yielding with carbon depletion rate of $0.3 \mathrm{Mg} \mathrm{Cha}^{-1}$ year $^{-1}$. The higher $\mathrm{C}$ sequestration of $\mathrm{CT}$ than business as usual practice was attributed to addition of previous plant residues, and a lower rate of soil organic matter decomposition with respect to $\mathrm{CT}$. Every season, the average weight of crop residue applied to the NT soil surface was 6-13 $\mathrm{Mg} \mathrm{ha}^{-1}$ season $^{-1}$ with a C-N ratio of around 32 (Utomo et al. 2010a).
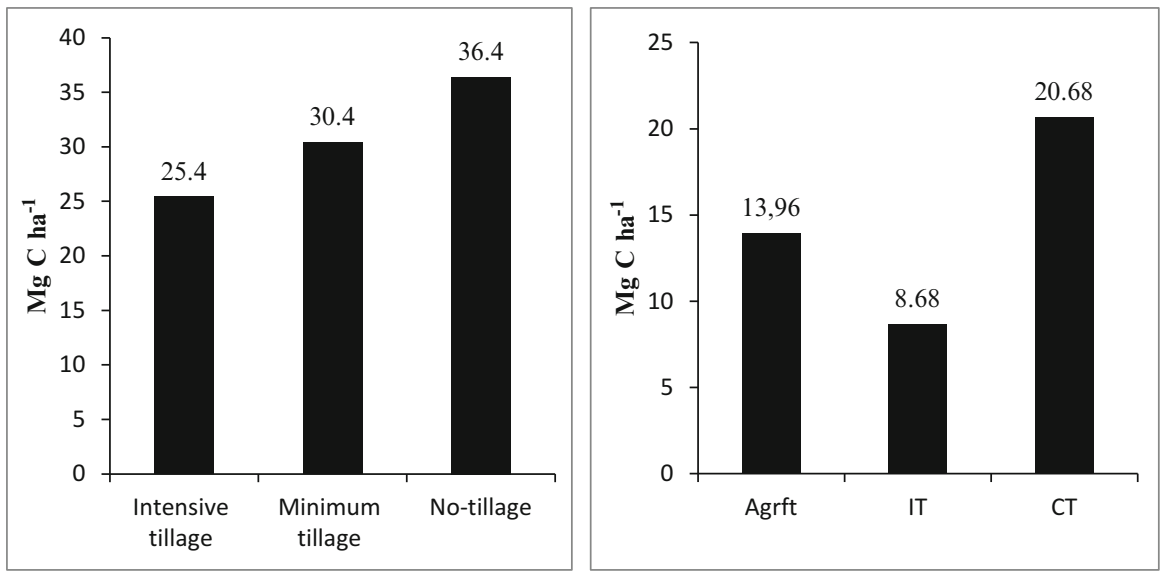

Fig. 4.3 Soil carbon storage at $0-20 \mathrm{~cm}$ depth after 23 years of conservation tillage (left) and farmers' fields $(r i g h t)$; Agrft $=$ agroforest, IT =intensive tillage, $\mathrm{MT}=$ minimum tillage, $\mathrm{NT}=$ notillage and $\mathrm{CT}=$ conservation tillage ( Utomo et al. 2010b) 
Table 4.1 Carbon balance of corn (during a single season)

\begin{tabular}{lllllll}
\hline Treatment & Root & Stalk & Grain & Total C-biomass $\left(\mathrm{Mg} \mathrm{Cha}^{-1}\right)$ & Emission & Net sequestration \\
\hline Intensive tillage & 1.2 & 3.6 & 2.5 & 7.3 & 2.0 & 5.3 \\
Minimum tillage & 1.6 & 3.4 & 4.5 & 9.5 & 1.5 & 8.0 \\
No-tillage & 2.1 & 5.3 & 5.0 & 12.4 & 1.0 & 11.4 \\
\hline
\end{tabular}

Note: With optimum fertilization (Utomo et al. 2011)

This higher soil carbon sequestration is also reflected in improved soil quality and crop productivity with respect to CT. Utomo et al. (2013) recently reported that compared to the IT corn field, the CT corn field after 23 years of cropping had higher soil moisture, soil exchange bases, and soil microbial biomass. The corn yield of long-term CT was also $31.8 \%$ higher than that of IT.

At the farmer's fields, that finding was confirmed by soil C storage at $0-20 \mathrm{~cm}$ depth under the different land use systems presented in Fig. 4.3, right. Soil C storage under CT farming was $138 \%$ higher than under IT farming and $48 \%$ higher than under rubber agroforest. The significant increase in soil $\mathrm{C}$ storage was attributable to the decomposition of previous crop residues and less soil erosion with respect to CT and rubber forest (Utomo et al. 2010b).

\subsubsection{Carbon Sequestration of Corn Crops}

Carbon sequestration of corn biomass was measured at harvest time. Through photosynthesis, plants fix $\mathrm{CO}_{2}$ from the air and convert it into organic carbon compounds that are used to grow plant tissues or biomass (Luo and Zhou 2006). The total carbon

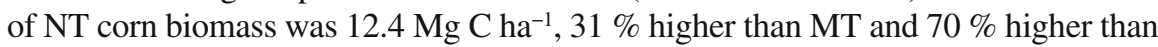
IT. With a better micro-climate and soil quality (Utomo et al. 2013), CT sequestered carbon in biomass at a higher level than other tillage systems, as reported by Lal (1997), Wright and Hons (2004), and Smith and Collins (2007). As shown in Table 4.1, NT's potential net sequestration reached $11.4 \mathrm{Mg} \mathrm{C} \mathrm{ha}^{-1}$, or $115 \%$ and $43 \%$ higher than IT and MT, respectively.

Dispite the fact that tillage systems generated $\mathrm{CO}_{2}$ emissions, howevr, all tillage systems also seqestered carbon at a rate higher than their $\mathrm{CO}_{2}$ emissions (Table 4.1). Thus, $\mathrm{CT}$ corn is not in fact a net $\mathrm{CO}_{2}$ emitter, but instead is a net sinker. In the final analysis, therefore, it is evident that $\mathrm{CT}$ farming using RMP can mitigate $\mathrm{CO}_{2}$ emission in a rain-fed tropical agro-ecosystem.

\subsection{Conclusions and Policy Implication}

In tropical rainfed agro-ecosystems, long-term conservation tillage of corn reduced $\mathrm{CO}_{2}$ emission and increased carbon sequestration both in biomass and soil. Long-term conservation tillage of corn was also an effective net sinker of carbon. 
However, further research is needed to improve the capacity of conservation tillage technology to mitigate greenhouse gas emissions in other crops and in different agro-ecosystems.

The policy implication of this strategic finding is that conservation tillage should be promoted by farmers, policy makers, and politicians as a recommended management practice for halting environmental degradation, reducing greenhouse gas emission, and strengthening food security.

Open Access This article is distributed under the terms of the Creative Commons Attribution Noncommercial License which permits any noncommercial use, distribution, and reproduction in any medium, provided the original author(s) and source are credited.

\section{References}

Al-Kaisi MM, Yin X (2005) Tillage and crop residue effects on soil carbon and carbon dioxide emission in corn-soybean rotations. J Environ Qual 34:437-445

Badan Pusat Statistik (BPS) (2012) Luas panen, produktivitas dan produksi tanaman jagung seluruh provinsi. Sensus Pertanian, Republik Indonesia 2013 (in Indonesian)

Ball AS, Pretty JN (2002) Agricultural influences on carbon emissions and sequestration. University of Essex, Colchester

Boer R (2010) Strategi mitigasi emisi GRK dari lahan. In: Centre for climate risk and opportunity management in South East Asia and Pacific (CCROM SEAP). Bogor Agricultural University, Kota Bogor

Brye KR, Longer DE, Gbur EE (2006) Impact of tillage and residue burning on carbon dioxide flux in a wheat-soybean production system. Soil Sci Soc Am J 70:1145-1154. SSSA, Madison, USA

Cole CV, Duxbury J, Freney J, Heinemeyer O, Minami K, Mosier A, Paustian K, Rosenberg N, Sampson N, Sauerbeck D, Zhao Q (1997) Global estimates of potential mitigation of greenhouse gas emissions by agriculture. Nutr Cycl Agroecosyst 49:221-228

Desjardins RL, Smith W, Grant B, Campbell C, Janzen H, Riznek R (2002) Management strategies to sequester carbon in agricultural soils and to mitigate greenhouse gas emissions. In: International workshop on reducing vulnerability of agriculture and forestry to climate variability and climate change. Ljubljana, 7-9 Oct 2002

Eggleston S, Buendia L, Miwa K, Ngara T, Tanabe K (2006) IPCC guidelines for national greenhouse gas inventories. Technical Report, IPCC

Haile-Mariam S, Collins HP, Higgins SS (2008) Greenhouse gas fluxes from an irrigated sweet corn (Zea mays L.)-potato (Solanum tuberosum L.) rotation. J Environ Qual 37:759-771

Intergovernmental Panel on Climate Change (IPCC) (2001) Climate change 2001: the scientific basis. Contribution of working group I to the third assessment report of the Intergovernmental Panel on Climate Change. Cambridge University Press, Cambridge

Intergovernmental Panel on Climate Change (IPCC) (2006) Guidelines for national greenhouse gas inventories. IPCC/IGES, Hayama

Lal R (1989) Conservation tillage for sustainable agriculture: tropics versus temperate environment. Adv Agron 42:85-197

Lal R (1997) Residue management, conservation tillage and soil restoration for mitigating greenhouse effect by $\mathrm{CO}_{2}$-enrichment. Soil Tillage Res 43:81-107

Lal R (2007) Soil carbon sequestration to mitigate climate change and advance food security. Soil Sci 32(12):943-956

Luo Y, Zhou X (2006) Soil respiration and the environment. Academic/Elsevier, Burlington, p 316 
Paustian K, Antle JM, Sheehan J, Paul EA (2006) Agriculture's role in greenhouse gas mitigation. Pew Center on Global Climate, Arlington, VA, USA, p 76

Pretty JN, Ball AS (2001) Agricultural influences on carbon emission and sequestration: a review of evidence and emerging trading options. In: Centre for environment and society occasional paper 2001-2003. University of Essex, Colchester, p 30

Rastogi M, Singh S, Pathak H (2002) Emission of carbon dioxide from soil. Curr Sci 82(5): $510-517$

Reicosky DC (2001) Effects of conservation tillage on soil organic carbon dynamics: field experiment in the U.S. corn belt. In: Scott DE, Mohtar RH, Steinhart GC (eds) Sustaining the global farm. Purdue University and the USDA-ARS National Soil Erosion Research Laboratory, Morris, MN, USA, pp 481-485

Ruddiman WF (2003) The anthropogenic greenhouse era began thousands of years ago. Clim Change 61:261-293

Scala L, Bolonhezi ND, Pereira GT (2005) Short-term soil $\mathrm{CO}_{2}-\mathrm{C}$ emission after conventional and reduced tillage of a no-till sugar cane area in southern Brazil. Soil Tillage Res 91(1-2): 244-248

Sedjo R, Sohngen B, Jagger P (1998) Carbon sinks in the post-Kyoto world, Internetth edn. Resources for the Future, Washington DC

Smith KE (2010) Effect of elevated $\mathrm{CO}_{2}$ and agricultural management on flux of greenhouse gases from soil. Soil Sci 175(7):349-356

Smith JL, Collins HP (2007) Management of organisms and their processes in soils. In: Paul EA (ed) Soil microbiology, ecology and biochemistry, 3rd edn. Academic, Burlington, p 532

Triplett GB, Dick WA (2008) No-tillage crop production: a revolution in agriculture. Agro J 100:S153-S156

Utomo M (2004) Olah tanah konservasi untuk budidaya jagung berkelanjutan. In: Prosiding Semi-nar Nasional IX Budidaya Pertanian Olah Tanah Konservasi, Gorontalo, 6-7 October 2004, pp 18-35 (in Indonesian)

Utomo M, Suprapto H, Sunyoto (1989) Influence of tillage and nitrogen fertilization on soil nitrogen, decomposition of alang-alang (Imperata cylindrica) and corn production of alang- alang land. In: Heide J van der (ed) Nutrient management for food crop production in tropical farming systems. Institute for Soil Fertility (IB), Haren (Gr.), the Netherlands, pp 367-373

Utomo M, Niswati A, Dermiyati WMR, Raguan AF, Syarif S (2010a) Earthworm and soil carbon sequestration after twenty one years of continuous no-tillage corn-legume rotation in Indonesia. J Int Fuzzy Syst 7:51-58

Utomo M, Buchari H, Banuwa IS (2010b) Peran olah tanah konservasi jangka panjang dalam mitigasi pemansan global: penyerapan karbon, pengurangan gas rumah kaca dan peningkatan produktivitas lahan. Laporan Akhir Hibah Kompetitif penelitian sesuai prioritas nasional. Tahun Kedua. DP2M (in Indonesian, unpublished)

Utomo M, Buchari H, Banuwa IS (2011) Peran olah tanah konservasi jangka panjang dalam mitigasi pemansan global: penyerapan karbon, pengurangan gas rumah kaca dan peningkatan produktivitas lahan. Laporan Akhir Hibah Kompetitif penelitian sesuai prioritas nasional. Tahun Kedua. DP2M (in Indonesian, unpublished)

Utomo M, Buchari H, Banuwa IS, Fernando LK (2012) Carbon storage and carbon dioxide emission as influenced by long-term conservation tillage and nitrogen fertilization in cornsoybean rotation. J Trop Soils 17(1):75-84

Utomo M, Banuwa IS, Buchari H, Anggraini Y, Berthiria (2013) Long-term tillage and nitrogen fertilization effects on soil properties and crop yields. J Trop Soils 18(20):21-30

Wright AL, Hons FM (2004) Soil aggregation and carbon and nitrogen storage under soybean cropping sequences. Soil Sci Soc Am J 68:507-513 